\title{
Identification of Major Proteins of a Very Stable High Molecular Mass Multi-Protein Complex of Human Placental Tissue Possessing Nine Different Catalytic Activities
}

\author{
Evgeniya E Burkova', Pavel S Dmitrenok ${ }^{2}$, Dmitrii V Bulgakov³, Evgeny A Ermakov', Valentina N Buneva', Svetlana E Soboleva' and \\ Georgy A Nevinsky ${ }^{1 *}$
}

${ }^{1}$ SB RAS Institute of Chemical Biology and Fundamental Medicine, Novosibirsk, Russia

${ }^{2}$ GB Elyakov Pacific Institute of Bioorganic Chemistry, Vladivostok, Russia

${ }^{3}$ Federal Scientific Center of the East Asia Terrestrial Biodiversity, Far Eastern Branch of Russian Academy of Sciences, Russia

\begin{abstract}
Human placenta is an organ protecting, feeding, and regulating the grooving of the embryo. Therefore, identification and characterization of placental components including proteins and their multi-protein complexes is an important step to understanding the placenta function.

Here we analyzed for the first time human placentas extremely stable multi-protein complex (SPC, $\sim 1000 \mathrm{kDa}$ ) by MALDI MS and MS/MS spectrometry using proteins tryptic hydrolyzates after proteins separation by SDS-PAGE and 2-D electrophoresis. The formation of such a very stable complex due to the random association of several various proteins is very unlikely. It was shown that SPCs contain twelve proteins: hemoglobin, alkaline phosphatase, cytoplasmic actin, human serum albumin, chorionic somatomammotropin hormone, heat shock protein beta-1, peroxiredoxin-1, 78 $\mathrm{kDa}$ glucose-regulated protein, protein disulfide isomerase A3, serotransferrin, annexin A5, and IgGs. These twelve proteins have in themselves many different and important biological functions, which can be inherent for these proteins in the complex. In addition, the complex demonstrated nine different enzymatic activities: DNase, RNase, ATPase, phosphatase, protease, amylase, catalase, peroxidase $\left(\mathrm{H}_{2} \mathrm{O}_{2}\right.$-dependent) and oxidoreductase $\left(\mathrm{H}_{2} \mathrm{O}_{2}\right.$-independent). The efficiency of the catalysis of each of these reactions by SPC preparations from three placentas was comparable. It was shown that hydrolysis of $r(p U) 23, r(p A) 23$, and $r(p C) 23$ leads to the formation of 1-22-mer oligonucleotides, while digestion of microRNA mirR137 is a site-specific (3A-4U >9U-10A $>8 \mathrm{U}-9 \mathrm{U} \geq 15 \mathrm{U}-16 \mathrm{~A})$ resulting in the formation of only four major products. A large number of potentially possible functions of the complex in accordance with the functions of its individual proteins are considered. Progress in the study of placental proteins complexes can promote understanding of their biological functions.
\end{abstract}

Keywords: Human placenta; Multi-protein complex; Protein complex; Catalytic activities

Abbreviations: DAB: 3,3'-Diaminobenzidine; HS: Human Serum Albumin; sTR: Serotransferrin; MALDI: Matrix-Assisted Laser Desorption/Ionization; MM: Molecular Mass; $\mathrm{m} / \mathrm{z}$ and $\Delta \mathrm{m} / \mathrm{z}$ : Ratio of Molecular Mass and Molecule Charge and Difference between these Values, respectively; MHS: a,D-maltoheptaose; pNPP: ParaNitrophenylphosphate; RA: Relative Activity; RON: Ribooligonucleatide; SDS-PAGE: SDS Polyacrylamide Gel Electrophoresis; SPC: Stable Soluble High Molecular Mass Multi-Protein Complex; WB: Western Blotting

\section{Introduction}

The placenta of mothers is much more than a filter: it is an organ protecting, feeding, and regulating the grooving of the embryo [1,2]. Progress in the study of the placenta and its components functioning can promote the development of transplantation methods. In spite of countless data obtained, placenta study still requires clarification of many important questions and some controversial results. Approximately $15 \%$ of all pregnancies are high-risk, resulting in the birth of premature babies, to increase the number of births by cesarean section as well as to prolonged maternal hospital stay, among others [3]. Identification and characterization of placentas proteins and their complexes are is important step for understanding the placenta functions.

It was argued that most biological processes are performed by many complexes of proteins [4]. For example, many cellular processes require several proteins and enzymes, which are association form larger stable or temporary protein complexes for the increase of the efficiency, new specificity and rate of metabolic pathways [4].
Soluble or solubilized proteins of placental extracts may be divided into three categories [1]: 1) proteins associated with pregnancy; 2) placental soluble proteins; 3) placental proteins associated with membranes. Soluble placental proteins circulate in the placenta fetal, and bloodstream and they are scarcely secreted into the blood of mothers.

During the last 30 years, more than 60 soluble placental enzymes and proteins and more than 100 various solubilized antigens of the placental membranes were identified by immunochemical methods [1-12]. Some of these proteins were analyzed using different physicochemical methods including MALDI mass spectrometry and/or sequencing of the full-length cDNA [7-11]. To date, most of the described proteomic analyses were focused on the comparison of placenta protein expression profiles of normal or diseased mothers $[9,11,12]$. Such data do not

*Corresponding author: Nevinsky GA, 1SB RAS Institute of Chemical Biology and Fundamental Medicine, Novosibirsk, Russia, Tel: +73833636126; Fax: +7 383363 51 53; E-mail: nevinsky@niboch.nsc.ru

Received: February 02, 2017; Accepted: February 28, 2018; Published March 09, 2018

Citation: Burkova EE, Dmitrenok PS, Bulgakov DV, Ermakov EA, Buneva VN, et al (2018) Identification of Major Proteins of a Very Stable High Molecular Mass MultiProtein Complex of Human Placental Tissue Possessing Nine Different Catalytic Activities. Biochem Anal Biochem 7: 351. doi: 10.4172/2161-1009.1000351

Copyright: (c) 2018 Burkova EE, et al. This is an open-access article distributed under the terms of the Creative Commons Attribution License, which permits unrestricted use, distribution, and reproduction in any medium, provided the original author and source are credited. 
Citation: Burkova EE, Dmitrenok PS, Bulgakov DV, Ermakov EA, Buneva VN, et al. (2018) Identification of Major Proteins of a Very Stable High Molecular Mass Multi-Protein Complex of Human Placental Tissue Possessing Nine Different Catalytic Activities. Biochem Anal Biochem 7: 351. doi: 10.4172/2161-1009.1000351

Page 2 of 9

provide information concerning possible protein complexes existing in placentas and their possible biological functions.

Placental membrane-associated proteins were analyzed by SDSPAGE and MALDI mass spectrometry [12]. 733 unique proteins and 34 known and novel heterooligomeric protein complexes were identified.

Using different methods, we have recently analyzed a possibility of an existence of multi-protein complexes in the soluble fraction of homogenates of human placentas [13]. Using gel filtration on Sepharose-4B, the extremely stable multi-protein complex (SPC, $\sim 1000 \pm 100 \mathrm{kDa}$ ) was separated from other placenta proteins. It was shown, that the SPC is stable in the presence of guanidinium chloride, acetonitrile, Triton $\mathrm{X100}, \mathrm{NaCl}$, and $\mathrm{MgCl}_{2}$ in high concentrations. This complex dissociates only in the presence of $8 \mathrm{M}$ urea, $0.5-1.0 \mathrm{M} \mathrm{NaCl}$, and $50 \mathrm{mM}$ EDTA. According to SDS-PAGE SPC contains several major and minor proteins with high, moderate, and low molecular masses, $14-79.3 \mathrm{kDa}[13]$.

Using different methods including MALDI mass MS and MS/MS spectrometry after SDS-PAGE, 2-D electrophoresis, here we analyzed and identified for the first time proteins of this very stable complex. In addition, it was shown that this very stable multi-protein complex is capable of catalyzing nine different chemical reactions.

\section{Materials and Methods}

\section{Chemicals and donors}

High purity reagents (Tris, $\mathrm{NaCl}$, SDS, EDTA, Bromphenol blue, glycerol, DTT, urea, Nonidet $\mathrm{P}-40, \mathrm{NH}_{4} \mathrm{HCO}_{3}$, trifluoroacetic acid, and some other compounds) were obtained from Sigma. Sepharose 4B was bought from Pharmacia (Sweden). Ethical statement: The placenta sampling protocol was approved by the local human ethics committee guidelines (Ethics committee of Novosibirsk State Medical University, Novosibirsk, Russia), which approved this study in accordance with Helsinki ethics committee guidelines. All healthy mothers gave written consent to present of their placentas for scientific purposes. Doctors provided us that placenta samples are from donors having no history of rheumatologic, respiratory, gastrointestinal, reproductive, cardiovascular, nervous system, or autoimmune pathologies.

Stable placental multi-protein complex purification and analysis Purification of the placental multi-protein complex was performed [13]. The homogenates of placentas after removal of insoluble compounds were subjected to gel filtration on Sepharose $4 \mathrm{~B}$ columns $(50 \mathrm{ml})$ equilibrated in TBS buffer $(20 \mathrm{mM}$ Tris- $\mathrm{HCl}, \mathrm{pH} 7.5$, containing 0.15 $\mathrm{M} \mathrm{NaCl}$. The proteins were eluted using the same TBS buffer. Fractions (3-4 ml) were collected and used for different type of analysis. The well separated stable protein complexes from three placentas have molecular masses (MMs) $\sim 1000 \pm 100 \mathrm{kDa}$. Very high stability of SPC was confirmed using its gel filtration in drastic conditions and light scattering approach [13].

\section{SDS-PAGE assay}

SDS-PAGE analysis of the intact complex proteins before and after SPC treatment with $50 \mathrm{mM}$ DTT was performed using Laemmli system: a $5-16 \%$ gradient gel containing $0.1 \%$ SDS. Before SDS-PAGE SPC preparations $(40-80 \mu \mathrm{g})$ were incubated for $20 \mathrm{~min}$ at $100^{\circ} \mathrm{C}$ in a buffer containing Tris- $\mathrm{HCl}$ (50 mM; pH 6.8), 1\% SDS, $0.001 \%$ bromophenol blue, $10 \%$ glycerol, $10 \mathrm{mM}$ EDTA in the presence or without $50 \mathrm{mM}$ DTT. Proteins were stained with Coomassie R-250. After SDS-PAGE, proteins transfer on nitrocellulose membrane was carried out [13].

\section{Trypsinolysis of proteins after electrophoresis}

Identification of SPC proteins was performed using MS and MS/ MS data from MALDI-TOF mass spectrometric analysis of their tryptic hydrolyzates after standard SDS-PAGE or after 2-D electrophoresis. In the case of 2-D electrophoresis, the separation of proteins was first carried out using devices for isoelectrofocusing of proteins (Protean IEF Cell, Bio-Rad, USA). SPC and solubilizing buffer containing $8 \mathrm{M}$ urea, $2 \%$ Nonidet $\mathrm{P}-40,0.2 \%$ ampholine $\mathrm{pH} 3-10$, and $50 \mathrm{mM}$ dithiothreitol were added in the IEF cell $(0.315 \mathrm{ml})$ according to manufacturer's procedure.

Then special linear IPG strips ( $\mathrm{pH} 3-10,18 \mathrm{~cm}$, Bio-Rad, USA) were used, which tops were layered with mineral oil. Strips were dehydrated passively for 1 hour, then actively for 12 hours. Isoelectrofocusing was performed at $250 \mathrm{~V}$ for $15 \mathrm{~min}$, then for 7 hours at $104 \mathrm{~V}$. IEF strips were then incubated for $30 \mathrm{~min}$ in buffer containing $0.38 \mathrm{M}$ Tris-HCI (pH 8.8), $6 \mathrm{M}$ urea, 20\% glycerol, 2\% SDS, and 0.001\% Bromphenol blue. Additional incubation was carried out using the same buffer, containing $100 \mathrm{mM}$ iodoacetamide without DTT. After the incubation, the strips were used for standard SDS-PAGE, and protein spots on the gels were revealed by Coomassie R-250 staining.

The Coomassie-stained gel fragments after SDS-PAGE were consequently washed twice with $100 \mu \mathrm{l}$ of water by shaking for $15 \mathrm{~min}$, and for removing of the dye were twice washed for $30 \mathrm{~min}$ with $50 \mu \mathrm{l} 50$ $\mathrm{mM} \mathrm{NH}_{4} \mathrm{HCO}_{3}$ containing $50 \%$ acetonitrile, and for removing of $\mathrm{H}_{2} \mathrm{O}$ gel fragments were washed with $100 \mu \mathrm{l}$ of $100 \% \mathrm{CH}_{3} \mathrm{CN}$ for $20 \mathrm{~min}$. Then fragments of the gels were dried for $10 \mathrm{~min}$ at $30^{\circ} \mathrm{C}$ using vacuum evaporator. For the hydrolysis of the proteins, $20 \mu \mathrm{l}$ of $25 \mathrm{mM} \mathrm{NH}_{4} \mathrm{HCO}_{3}$ containing $12.5 \mu \mathrm{g} / \mathrm{ml}$ of sequencing grade trypsin (Promega) was added and after mixture incubation for $45 \mathrm{~min}$ at $0^{\circ} \mathrm{C}$ the solution was removed. The gel fragments were incubated additionally with $20 \mu \mathrm{l}$ $25 \mathrm{mM} \mathrm{NH}_{4} \mathrm{HCO}_{3}$ for 18 hours at $37^{\circ}$ and solution was removed. For additional extraction of the peptides, the gel fragments were washed twice with $25 \mu \mathrm{l}$ of $50 \mathrm{mM} \mathrm{NH}_{4} \mathrm{HCO}_{3}$ containing $50 \%$ acetonitrile with shaking for $15 \mathrm{~min}$. Fractions obtained after three treatments of the gel were pooled, lyophilized, dissolved in $20 \mu \mathrm{l}$ water and used for subsequent MALDI-TOF mass spectrometric analysis.

\section{Analysis by MALDI-TOF mass spectrometry of the SPC proteins}

All mass spectra were acquired with an Autoflex (Bruker Daltonics, Bremen, Germany) MALDI-TOF mass spectrometer with a nitrogen laser operated in the positive reflector mode (standard method RP 7003500 Da.par) under the control of Flex Control software (version 3.4; Bruker Daltonics). Saturated solution a-cyano-4-hydroxycinnamic acid was used as the matrix; the acid was solved in $0.1 \%$ trifluoroacetic acid and acetonitrile (1:2). To $2 \mu \mathrm{l}$ of the reaction mixture containing analyzed component, $2 \mu \mathrm{l}$ of a mixture of $0.2 \%$ trifluoroacetic acid and matrix were added; $1 \mu \mathrm{l}$ of the final mixtures were spotted on the MALDI standard steel plates, air-dried, and used for the analysis.

The analysis was performed in the automatic mode (AutoXecute - automatic Run). The spectra were externally calibrated using the Calibrate Peptide Standards; FAMS Method and a standard calibration mixture (Protein Calibration Standard I, Bruker Daltonics). The data files were transferred to Flexanalysis software version 3.4 (Bruker Daltonics) for automated peak extraction. Assignment of the first monoisotopic signals in the spectra was performed automatically using the signal detection algorithm SNAP (Bruker Daltonics).

For MS and MS/MS analyses, we used the PMF. FAMS Method and SNAP_full_process, FALIFT Method, respectively. Each spectrum 
Citation: Burkova EE, Dmitrenok PS, Bulgakov DV, Ermakov EA, Buneva VN, et al. (2018) Identification of Major Proteins of a Very Stable High Molecular Mass Multi-Protein Complex of Human Placental Tissue Possessing Nine Different Catalytic Activities. Biochem Anal Biochem 7: 351. doi: 10.4172/2161-1009.1000351

was obtained by averaging 1500-5000 laser shots (300 shots in a step) acquired at the minimum laser power. The data were analysed using BioTools (version 3.2; Bruker Daltonics). A peptide mass tolerance of $0.5 \mathrm{Da}$ and a fragment mass tolerance of $0.5 \mathrm{Da}$ were adopted for database searches. The $\mathrm{m} / \mathrm{z}$ spectra were searched against the NCBInr and SwissProt databases using the Mascot search engine. Threshold score was 40. Protein identifications were accepted if they were established at score significantly greater than 40 (3-5 repeats) and contained at least three identified peptides, using the Mascot search engine. Further data were analyzed using 2016 SwissProt program and UniProt (http://www.uniprot.org/uniprot/).

\section{DNase activity assay}

DNase activity of SPCs was analyzed using supercoiled (sc) DNA pBluescript. The reaction mixture $(20 \mu \mathrm{l})$ contained $50 \mathrm{mM}$ Tris- $\mathrm{HCl}, 5$ $\mathrm{mM} \mathrm{MgCl}, 1 \mathrm{mM}$ EDTA, $20 \mu \mathrm{g} / \mathrm{ml}$ (or $6.7 \mathrm{nM}$ ) supercoiled (sc) DNA, (pH 7.5), and $25 \mu \mathrm{g} / \mathrm{ml}$ one of three SPCs, and was incubated for $2 \mathrm{~h}$ at $37^{\circ} \mathrm{C}[14]$. The products of cleavage were analyzed using electrophoresis in $0.8 \%$ agarose gel with the subsequent coloring of the DNA by ethidium bromide. The pictures of ethidium bromide-stained gels were captured using Sony DSC-F717 camera. The hydrolysis of scDNA leads to forming its relaxed form, which has a lower electrophoretic mobility. The initial native scDNA always contains small amount of hydrolyzed relaxed DNA. The relative intensity of DNA in different bands was analyzed by ImageQuant v5.2 (Molecular Dynamics). The SPCs activities were first determined as a decrease in the percent of scDNA converted from the initial supercoiled form to its relaxed form. The data were corrected for the distribution of DNA between these two bands in control after incubation of the plasmid in the absence of the SPCs. All initial rates were estimated within the linear regions of the time courses (15-40\% of DNA hydrolysis). Taking into account the DNA content in the reaction mixture $(6.7 \mathrm{nM})$, the percentage of the hydrolysis for $2 \mathrm{~h}$ was recalculated into the amount of hydrolyzed DNA $(\mathrm{nM} / 1 \mathrm{~h})$. Using the concentration of SPCs (16-25 mg/l), the specific activity of SPCs was calculated from three independent experiments as $\mathrm{pmole} \mathrm{DNA} / \mathrm{h} / \mathrm{mg}$ of SPC.

\section{RNase activity assay}

As the substrate for analysis of RNase activity, we have used four substrates: three 5'-fluorescently labeled 23-mer homo-ribooligonucleotides $\quad(\mathrm{RONs})$ : $\quad$ Flu-r $(\mathrm{pA})_{23}, \quad$ Flu-r $(\mathrm{pU})_{23}$ Flu-r(pC) $)_{23}$ and one 23-mer microRNA (Flu-miR-137; 5'-FluUUAUUGCUUAAGAAUACGCGUAG) [15]. All these RONs contained fluorescent residue fluorescein (Flu) on their 5'-terminus.

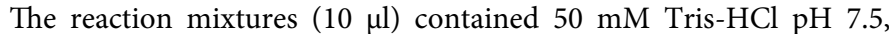
$0.01 \mathrm{mg} / \mathrm{ml}$ one of RONs and $2 \times 10^{-5-6} \times 10^{-3} \mathrm{mg} / \mathrm{ml}$ one of three different SPCs. The reaction mixtures were incubated for $1 \mathrm{~h}$ at $37^{\circ} \mathrm{C}$. After incubation, $10 \mu \mathrm{l}$ of a denaturing buffer consisting of 8 $\mathrm{M}$ urea and $0.025 \%$ xylenicanol was added. To obtain markers of the oligonucleotide length, the limited alkaline hydrolysis of RONs was performed. The reaction mixture under alkaline hydrolysis contained $0.05 \mathrm{M} \mathrm{NaHCO}_{3}-\mathrm{Na}_{2} \mathrm{CO}_{3}$ buffer, $\mathrm{pH} 9.5$, and $0.02 \mathrm{mg} / \mathrm{ml} \mathrm{RNA}$. After incubation for 15 minutes at $90^{\circ} \mathrm{C}$, the reaction mixture was cooled, and a volume of denaturing buffer equal to the volume of the reaction mixture was added thereto. The hydrolysis products were analyzed by electrophoresis. Electrophoresis (10 $\mu \mathrm{l}$ of mixture) was performed under denaturing conditions (20\% acrylamide (30:1), $8 \mathrm{M}$ urea, TBE buffer, $\mathrm{pH} 8.3$ ( $89 \mathrm{mM}$ Tris, $89 \mathrm{mM} \mathrm{H}_{3} \mathrm{BO}_{3}$ and $2 \mathrm{mM}$ EDTA) at $800 \mathrm{~V}$ and $40 \mathrm{~mA}$ for 3 hours. The results of electrophoresis were recorded on a Typhoon FLA 9500 laser scanner (GE Healthcare). First the activity of the complexes was calculated from a decrease (\%) in the amount of intact RONs in comparison control experiments without SPCs (100\%) at their fixed concentrations $\left(2 \times 10^{-5-6} \times 10^{-3} \mathrm{mg} / \mathrm{ml}\right)$. Considering the molecular weight of each ORN, the percentage of its hydrolysis was recalculated into the amount of hydrolyzed substrate, $\mathrm{mM} \mathrm{ORN/h}$ using the concentration of SPCs $(6.0 \mathrm{mg} / \mathrm{l})$, the specific activity of RNase activity of SPCs was calculated from three independent experiments as $\mathrm{mM}$ ORN/h/mg of SPC.

\section{ATPase and phosphatase activities of the SPCs}

For estimation of ATPase activity reaction mixture $(20 \mu \mathrm{l})$ contained $50 \mathrm{mM}$ Tris- $\mathrm{HCl}, \mathrm{pH} 7.5,1 \mathrm{mM} \mathrm{MgCl}, 0.3 \mathrm{mM}$ EDTA, $1.0 \mathrm{mM}$ ATP, and $0.05 \mathrm{mg} / \mathrm{ml}$ one of SPCs by analogy [14] with some modifications. The mixtures were incubated for $0-2$ hours at $37^{\circ} \mathrm{C} ; 3 \mu \mathrm{l}$ aliquots were applied to PEI-cellulose plates, and thin-layer chromatography was performed using $0.25 \mathrm{M}$ potassium phosphate buffer $\mathrm{pH}$ 7.0. The plates were dried and photographed. The level of ATP hydrolysis (\%) was determined from the ratio of relative fluorescence of unhydrolyzed ATP and products of its hydrolysis estimated by Image Quant 5.2. The specific ATPase activity of SPCs was calculated from a decrease in the amount of intact ATP (\%) at its fixed concentration, and then specific activity was expressed as M ATP/h/mg of SPC.

For analysis of phosphatase activity the reaction mixture $(80$ $\mu \mathrm{l})$ contained $20 \mathrm{mM}$ Tris $\mathrm{HCl}, \mathrm{pH} 9.0,10 \mathrm{mM} \mathrm{MgCl}, 5 \mathrm{mM}$ paranitrophenylphosphate (pNPP), and $0.05 \mathrm{mg} / \mathrm{ml} \mathrm{SPC}$. The accumulation of the colored product was measured at a wavelength of $400 \mathrm{~nm}$ for $0-30 \mathrm{~s}$ [16]. The specific activities of SPCs were calculated from an increase in optical density at $400 \mathrm{~nm}\left(\mathrm{~A}_{400}\right)$, and specific activity was expressed as $\mathrm{M} \mathrm{pNPP} / \mathrm{h} / \mathrm{mg}$ of SPC using extinction coefficient equal to $18300 \mathrm{M}^{-1} \mathrm{sm}^{-1}[16]$.

\section{Protease activity of the SPCs}

Protease activity of the SPCs was measured by the standard method using azocasein as substrate [17]. The reaction mixture $(30 \mu \mathrm{l})$ contained $50 \mathrm{mM}$ Tris- $\mathrm{HCl}$ ( $\mathrm{pH} 7.5), 3.3 \mathrm{mg} / \mathrm{ml}$ azocasein, and $0.017 \mathrm{mg} / \mathrm{ml} \mathrm{SPC}$. It was incubated for 20 hours at $37^{\circ} \mathrm{C}$ and then was stopped by adding of $24 \mu \mathrm{l}$ of $20 \%$ trichloroacetic acid and centrifuged at 13,000 rpm for 1 min. An equal volume of $1 \mathrm{M} \mathrm{NaOH}$ was added to the supernatant and allowed mixture to stand at room temperature for $30 \mathrm{~min}$.

Then the mixture was centrifuged at 13,000 rpm for 3 minutes, the supernatant was collected and the absorbance measured at a wavelength of $436 \mathrm{~nm}\left(\mathrm{~A}_{436}\right)$ against the buffer (50 mM Tris- $\mathrm{HCl}, \mathrm{pH}$ 7.5). The optical density increase due to the elimination of azo dye from casein was measured. The specific activity was expressed as $\mathrm{A}_{436}$ of azocasein $/ \mathrm{h} / \mathrm{mg}$ of SPC.

\section{Amylase activity of SPCs}

To analyze the amylase activity of SPCs, the reaction mixture $(15 \mu \mathrm{l})$ contained $30 \mathrm{mM}$ Tris- $\mathrm{HCl}, \mathrm{pH}$ 7.5, $5 \mathrm{mM}$ a,D-maltoheptaose (MHS) and $0.05 \mathrm{mg} / \mathrm{ml}$ one of three SPCs. The mixtures were incubated for 24 hours at $30^{\circ} \mathrm{C}$ by analogy [18] with some modifications. The hydrolysis products were analyzed by ascending thin layer chromatography on Kieselgel $\mathrm{F}_{254}$ (Merck) plates with aluminum base in the system: acetic acid: butanol-1: water (4:12:4) [18]. The plates were dried, treated with a solution containing $12.5 \%$ concentrated $\mathrm{H}_{2} \mathrm{SO}_{4}$ in $87.5 \%$ isopropyl alcohol, dried over a heater to visualize the hydrolysis products. The specific activity of SPCs was estimated from the decrease of the initial oligosaccharide (\%) taking into account distribution of its hydrolyzed forms after reaction mixture incubation without protein complexes and expressed as $\mathrm{mM} \mathrm{MHS} / \mathrm{h} / \mathrm{mg}$ SPC. 
Citation: Burkova EE, Dmitrenok PS, Bulgakov DV, Ermakov EA, Buneva VN, et al. (2018) Identification of Major Proteins of a Very Stable High Molecular Mass Multi-Protein Complex of Human Placental Tissue Possessing Nine Different Catalytic Activities. Biochem Anal Biochem 7: 351. doi: 10.4172/2161-1009.1000351

Page 4 of 9

\section{Catalase activity assay}

Measurement of the catalase activity was carried out [19]. For an accurate estimation of peroxide concentration, we have used its manganometric determination [20]. Found by us concentration of hydrogen peroxide within the error of the method $( \pm 3 \%)$ was as indicated on the manufacturer's packaging. Reaction mixture contains $50 \mathrm{mM} \mathrm{K}$-phosphate $(\mathrm{pH} 7.0), 30 \mathrm{mM} \mathrm{H}_{2} \mathrm{O}_{2}$, and $0.01 \mathrm{mg} /$ $\mathrm{ml}$ one of SPCs. Catalase activity was estimated from a decrease in $\mathrm{A}_{240}$ absorbance for $1-10 \mathrm{~min}$ at $25^{\circ} \mathrm{C}$ caused by the disproportionation of $\mathrm{H}_{2} \mathrm{O}_{2}$ using Varian Cary 50 UV-VIS (Agilent). Initial rates were determined from the linear regions of the kinetic curves using SPCs concentrations corresponding to linear part of the dependences upon their concentrations. Like in the case of determination of the specific activity of enzymes, this approach allowed normalization of the relative activity to any standard condition. For the calculation of the activity, the molar extinction coefficient of hydrogen peroxide $\left(\varepsilon=81 \mathrm{M}^{-1} \mathrm{~cm}^{-1}\right)$ was used [19]. The measured relative activity of IgGs was normalized to standard conditions: $\mathrm{mM} \mathrm{H}_{2} \mathrm{O}_{2} / \mathrm{min} / \mathrm{mg}$ of SPC.

\section{Peroxidase and oxidoreductase activities assays}

The reaction mixture $(100 \mu \mathrm{l})$ for analysis of peroxidase $\left(\mathrm{H}_{2} \mathrm{O}_{2}\right.$ dependent oxidation) and oxidoreductase $\left(\mathrm{H}_{2} \mathrm{O}_{2}\right.$-independent oxidation) activities consisted of $25 \mathrm{mM} \mathrm{K}$-phosphate ( $\mathrm{pH} 6.8$ ), 0.2

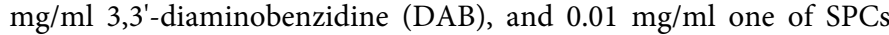
[21]. Reaction mixtures for analysis of peroxidase activity contain 10 $\mathrm{mM} \mathrm{H}_{2} \mathrm{O}_{2}$, while oxidoreductase activity was analyzed using the same mixture containing no $\mathrm{H}_{2} \mathrm{O}_{2}$. The reaction mixtures were incubated in cells of immunological plates in the dark at $22^{\circ} \mathrm{C}$ for $1-20$ minutes, measuring the amount of colored product formed every 30 to 120 seconds. The optical density of the solutions $\left(\mathrm{A}_{450}\right)$ was determined using a Labsystems Uniskan II spectrophotometer. The reaction mixtures containing no SPCs were used as controls. Initial reaction rates were determined using the Origin 8.5 program from the slopes of the linear parts of the kinetic curves; SPC concentration corresponds to the linear sections of the reaction rate dependence on the concentration of SPC. The activity was first expressed in units of $\mathrm{A}_{450} / \mathrm{min} / \mathrm{mg}$ SPC and then as $\mathrm{mM} \mathrm{DAB} / \mathrm{min} / \mathrm{mg}$ SPC using molar extinction coefficient of DAB oxidized product, $\varepsilon=27850 \mathrm{M}^{-1} \mathrm{~cm}^{-1}$ [21].

\section{Statistical Analysis}

The results are reported as mean \pm S.E. from at least two-three independent experiments for each sample of the complex and every catalytic activity.

\section{Results}

\section{Isolation and analysis of placental protein complex}

We have purified soluble SPCs from fresh human extracts of placentas by gel filtration on Sepharose 4B [13]. Figure 1 demonstrates a typical profile of gel filtration of concentrated extract of one fresh placenta. Similarly [13], it was shown that this complex efficiently dissociates only in the presence of $8 \mathrm{M}$ urea containing $0.5-1.0 \mathrm{M} \mathrm{NaCl}$, 50 mM EDTA.

\section{Analysis of SPC proteins by MALDI mass spectrometry af- ter2-D electrophoresis}

The SPC with MMs about $1000 \pm 100 \mathrm{kDa}$ was first analyzed by standard SDS-PAGE [13]. Several minor, average, and major protein bands were revealed. Here for identification of SPC proteins we have used 2-D electrophoresis and observed 32 visible protein spots in the case of the complex from the first (SPC-1; Figure 2) and 44 protein spots

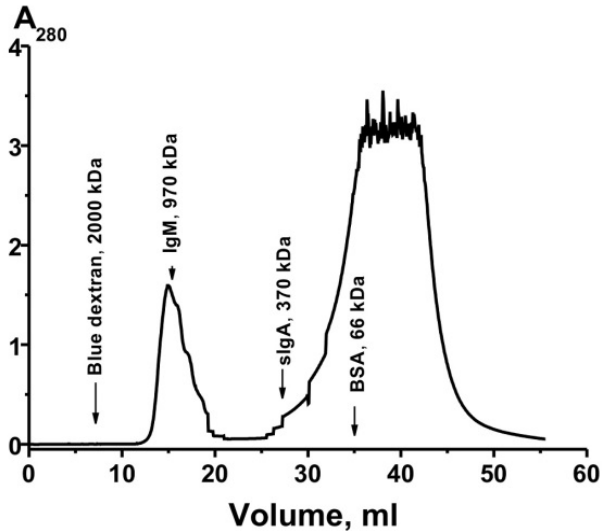

Figure 1: Gel filtration of proteins corresponding to the extract of one placenta donor on a Sepharose 4B column. The placenta extract before gel filtration was concentrated: $(-)$, absorbance at $280 \mathrm{~nm}\left(\mathrm{~A}_{280}\right)$. For ddetails, see Materials and methods.

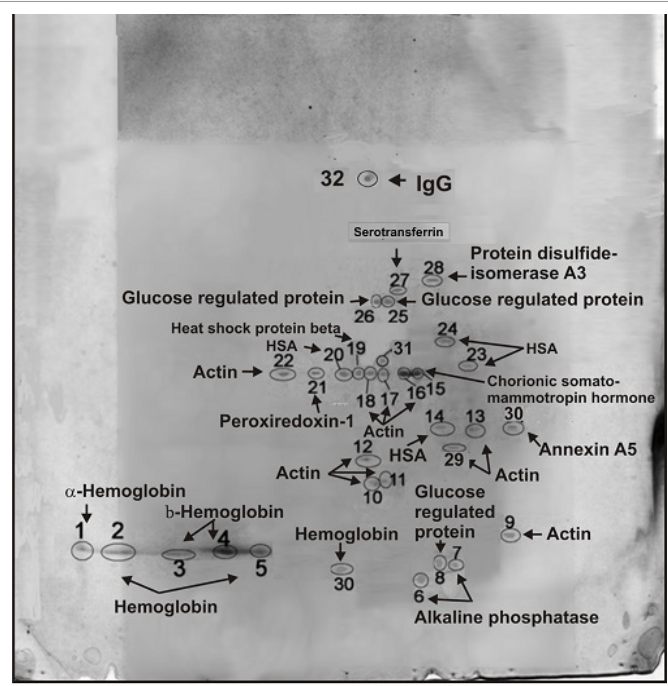

Figure 2: Two-dimensional gel electrophoresis of the SPC-1. The proteins were first separated by isoelectrofocusing and then SDS-PAGE in denaturing conditions. The spots were stained with Coomassie R-250, then cut, proteins we subjected to proteolysis for their identification using MALDI mass MS and MS/MS spectrometry. All identified proteins and their numbers are shown in the figure.

of the complex from the second placenta (SPC-2; Figure 3). Only 12 visible major and moderate proteins and their different isoforms were identified using MALDI mass MS/MS data of proteins hydrolysates corresponding to the protein sports after 2-D electrophoresis (Table 1). The data of protein identification using MS and MS/MS analysis of tryptic hydrolysates are given in Supplementary Table 1.

Interestingly, only one protein spot corresponded to heat shock protein beta-1, peroxiredoxin-1, and serotransferrin (sTR) in SPC-1 and SPC-2. Several proteins were represented by one spot in the case of SPC-1, but 2-4 spots for SPC-2: chorionic somatomammotropin hormone, IgG, annexin A5, protein disulfide isomerase A3. All other spots correspond to different isoforms of placenta proteins (number of spots for SPC-1 and SPC-2, respectively): hemoglobin (6 and 6), alkaline phosphatase (2 and 2), $78 \mathrm{kDa}$ glucose regulate protein ( 3 and 2), cytoplasmic actin (11 and 14), HSA (4 and 6) (Table 1). Four of these proteins (sTR, annexin A5, IgG, and HSA) were identified not only using MALDI spectrometry but also additionally by Western 
Citation: Burkova EE, Dmitrenok PS, Bulgakov DV, Ermakov EA, Buneva VN, et al. (2018) Identification of Major Proteins of a Very Stable High Molecular Mass Multi-Protein Complex of Human Placental Tissue Possessing Nine Different Catalytic Activities. Biochem Anal Biochem 7: 351. doi: 10.4172/2161-1009.1000351

Page 5 of 9

blotting (WB) after SDS-PAGE (Figure 4 and Table 1). The fact that stable complexes from different placentas contain mainly a limited number of the same proteins may be indicative of their non-random but specific association.

\section{Enzymatic activities of the SPCs}

The SPCs could contain not only proteins but also different

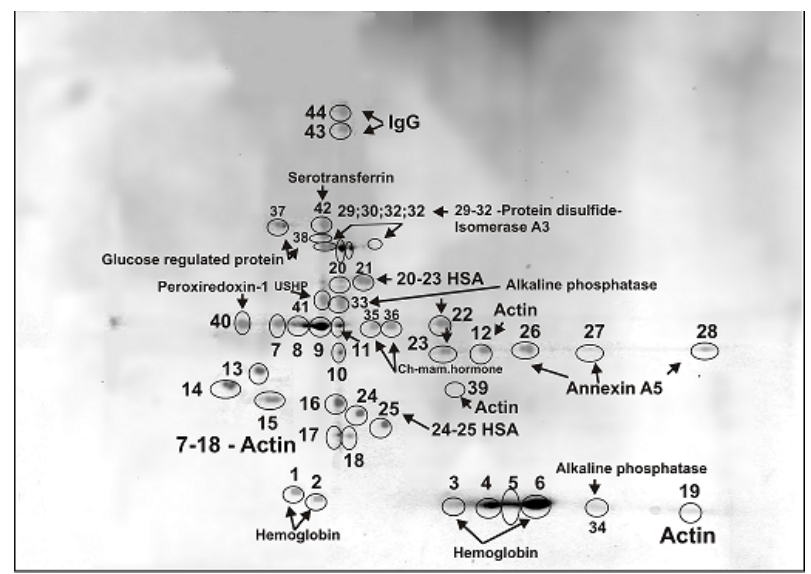

Figure 3: Two-dimensional gel electrophoresis of the SPC-2. The proteins were first separated by isoelectrofocusing and then SDS-PAGE in denaturing conditions. The spots were stained with Coomassie R-250, then cut, proteins we subjected to proteolysis for their identification using MALDI mass MS and MS/MS spectrometry. All identified proteins and their numbers are shown in the figure.

\begin{tabular}{|c|c|c|c|c|c|c|}
\hline \multirow{3}{*}{$\begin{array}{c}\begin{array}{c}\text { Number } \\
\text { of protein }\end{array} \\
1\end{array}$} & \multirow{3}{*}{\begin{tabular}{|l} 
Identified protein \\
$\begin{array}{l}\text { Hemoglobin subunit } \\
\text { beta+alpha+gamma }\end{array}$
\end{tabular}} & \multicolumn{2}{|c|}{$\begin{array}{c}\text { Numbers of protein } \\
\text { bands (the amount of } \\
\text { spots) }\end{array}$} & \multirow{2}{*}{\multicolumn{2}{|c|}{$\begin{array}{c}\text { Methods of } \\
\text { identification }\end{array}$}} & \\
\hline & & \multirow{2}{*}{\begin{tabular}{|l|} 
Placenta 1 \\
$1-5,30(6)$
\end{tabular}} & \multirow{2}{*}{$\begin{array}{c}\text { Placenta } 2 \\
1-6(6)\end{array}$} & & & \\
\hline & & & & $\mathrm{MS}^{\mathrm{a}}$ & $\mathrm{MS} / \mathrm{MS}^{\mathrm{b}}$ & \\
\hline 2 & $\begin{array}{c}\text { Alkaline } \\
\text { phosphatase }\end{array}$ & $6,7(2)$ & $33,34(2)$ & $\mathrm{MS}^{\mathrm{a}}$ & $\mathrm{MS} / \mathrm{MS}^{\mathrm{b}}$ & \\
\hline 3 & $\begin{array}{l}78 \mathrm{kDa} \text { glucose } \\
\text { regulate }\end{array}$ & $8,25,26(3)$ & $37,38(2)$ & MS & MS/MS & \\
\hline 4 & $\begin{array}{l}\text { Protein Actin, } \\
\text { cytoplasmic }\end{array}$ & $\begin{array}{c}9-13,16-18 \\
22,29,31 \\
(11)\end{array}$ & $\begin{array}{l}7-19 \\
39(14)\end{array}$ & MS & MS/MS & \\
\hline 5 & $\begin{array}{l}\text { Human serum } \\
\text { albumin }\end{array}$ & $\begin{array}{c}14,20,23 \\
24(4)\end{array}$ & $20-25(6)$ & MS & MS/MS & $\mathrm{IB}^{\mathrm{c}}$ \\
\hline 6 & $\begin{array}{l}\text { Chorionic somato- } \\
\text { mammotropin } \\
\text { hormone }\end{array}$ & $15(1)$ & $35,36(2)$ & MS & MS/MS & \\
\hline 7 & $\begin{array}{l}\text { Heart shock protein } \\
\text { beta-1 }\end{array}$ & $19(1)$ & $41(1)$ & MS & MS/MS & \\
\hline 8 & Peroxiredoxin-1 & $21(1)$ & $40(1)$ & MS & MS/MS & \\
\hline 9 & Serotransferrin & $27(1)$ & $42(1)$ & MS & MS/MS & IB \\
\hline 10 & $\begin{array}{l}\text { Protein disulphide } \\
\text { isomerase A3 }\end{array}$ & $28(1)$ & $29-32(4)$ & MS & MS/MS & \\
\hline 11 & Annexin A5 & $30(1)$ & $26-28(3)$ & MS & MS/MS & IB \\
\hline 12 & $\lg G$ & $32(1)$ & $43,44(2)$ & MS & MS/MS & IB \\
\hline
\end{tabular}

a MS - identification on the basis of a set of different peptides of proteins tryptic hydrolysates.

bMS/MS according to the sequences of the peptides (from three to eleven peptides).

'Analyzed not only my by MS/MS, but also using immunoblotting (IB).

Table 1: Proteins of the stable complexes purified from placentas 1 and 2 (Figures 2 and 3$)$.

\section{1 STR AN HSA IgG}

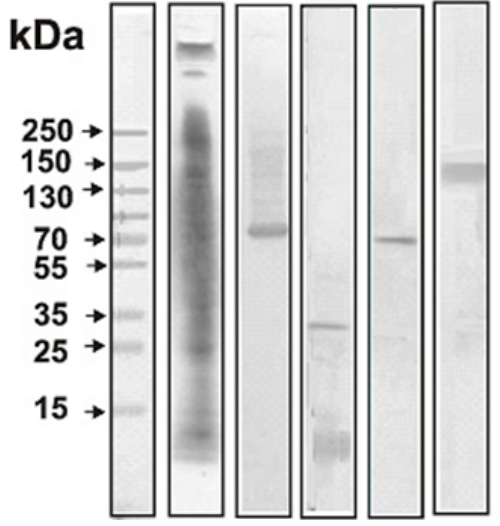

Figure 4: Immunoblotting analysis of SPC-2 proteins. After SDS-PAGE, proteins transfer were transferred on nitrocellulose membrane. The membrane was colored with silver (lane 1) or treated with monoclonal mouse Abs (conjugated with horseradish peroxidase) against human serotransferrin (LF), annexin A5 (AN), IgG, and HSA. The arrows (lane C) show the positions of molecular mass markers.

A

$\begin{array}{lllllllllll}1 & 2 & 3 & 1 & 2 & 3 & 1 & 2 & 3 & \mathrm{C}\end{array}$
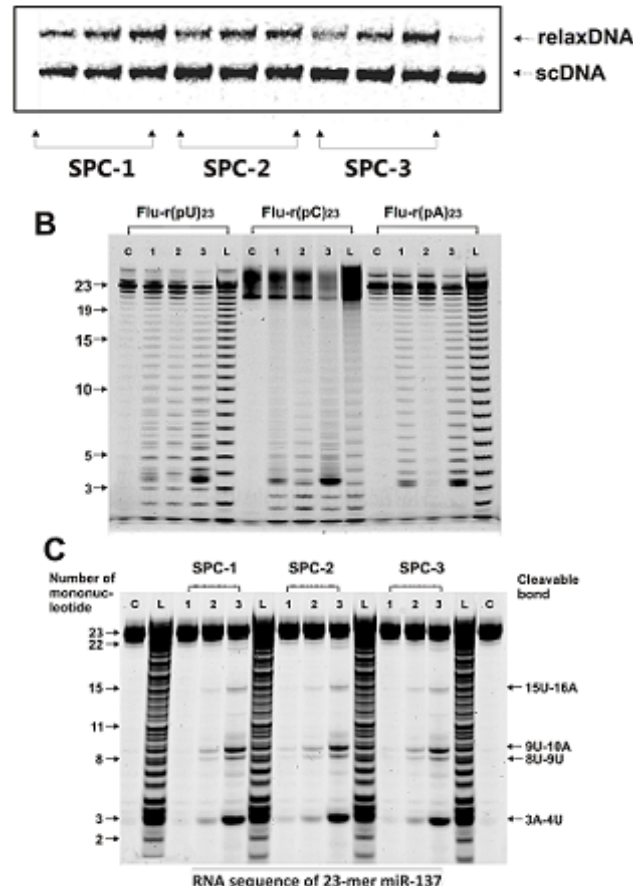

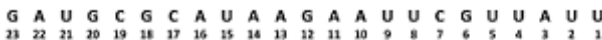

Figure 5: Analysis of DNase activity of three SPCs (lanes 1-3) in the hydrolysis of supercoiled (sc) DNA plasmid resulting in a formation of relaxed plasmid (relaxDNA) (A). scDNA was incubated at $37^{\circ} \mathrm{C}$ for $2 \mathrm{~h}$ with the SPCs; lanes 1-3 correspond to $1.6 \times 10^{-2}, 2.1 \times 10^{-2}$, and $2.5 \times 10^{-2} \mathrm{mg} / \mathrm{ml}$ of three SPCs, respectively. Lane $\mathrm{C}$ corresponds to scDNA incubated in the absence of the complex. The patterns of Flu- $r(\mathrm{pU})_{23}$, Flu- $\mathrm{r}(\mathrm{pC})_{23}$, and Flu- $\mathrm{r}(\mathrm{pA})_{23}$ hydrolysis for 1 $\mathrm{h}$ by $6 \times 10^{-3} \mathrm{mg} / \mathrm{ml} \mathrm{SPC}-1$ (lanes 1 ), SPC-2 (lanes 2), SPC-3 (lanes 3 ) (B). The patterns of Flu-miR-137 hydrolysis for $1 \mathrm{~h}$ by SPC-1, SPC-2, SPC-3 in different concentrations: lane 1-2 × $10^{-5}$, lane $2-2 \times 10^{-4}$, and lane $3-2 \times 10^{-3} \mathrm{mg} / \mathrm{ml}(\mathrm{C})$. Lanes C correspond to RONs incubated without SPCs, while lanes L - to the mixture of RON after its statistical alkaline hydrolysis. The products of hydrolysis were detected by their fluorescence due to the fluorescent residue (Flu) on their 5 '-ends. The lengths of the products of RONs hydrolysis by each preparation are indicated in the panels. 
Citation: Burkova EE, Dmitrenok PS, Bulgakov DV, Ermakov EA, Buneva VN, et al. (2018) Identification of Major Proteins of a Very Stable High Molecular Mass Multi-Protein Complex of Human Placental Tissue Possessing Nine Different Catalytic Activities. Biochem Anal Biochem 7: 351. doi: 10.4172/2161-1009.1000351

enzymes. In addition, the active sites catalyzing different reactions can sometimes be formed at the interface of proteins possessing no catalytic activities in their free states. Sometimes some proteins in an individual state may have an incompletely formed active center with a very weak activity. The formation of a complete centre with increased activity can occur at the junction of subunits of different enzymes or proteins [4]. Here it was shown that three SPCs possess nine different activities: DNase, RNase, ATPase, phosphatase, protease, amylase, catalase, peroxidase $\left(\mathrm{H}_{2} \mathrm{O}_{2}\right.$-dependent oxidation of substrate $)$ and oxidoreductase $\left(\mathrm{H}_{2} \mathrm{O}_{2}\right.$-independent oxidation of substrate) activities.

The relative activity (RA) in scDNA hydrolysis of three SPCs was estimated (Figure 5A). These values were comparable in the case of all three preparations (Table 2). Figure $5 \mathrm{~B}$ demonstrates the patterns of Flu-r(pU) ${ }_{23}$, Flu-r(pC) $)_{23}$, and Flu-r(pA) $)_{23}$ hydrolysis by three SPC preparations. It can be seen that the hydrolysis of these 23-mer homoribooligonucleotides (homo-RONs) by all three preparations occurs almost statistically with the formation of products having a length from 1 to 22 nucleotide units. Only the cleavage products at one of all sites corresponding to the $3 \mathrm{~N}-4 \mathrm{~N}$ sequences from the 5 '-end of all three Flu$\mathrm{r}(\mathrm{pN})_{23}$ are major. The relative RNase activities of all three SPCs are to some extent comparable, but still, SPC-3 more efficiently hydrolyzes all three homo-RONs. Interestingly, unlike homo-RONs, hydrolysis of hetero-microRNA Flu-miR-137 is a site-specific in the case of all three SPCs (Figure 5C). Hydrolysis of Flu-miR-137 occurs mainly on four sites: $3 \mathrm{~A}-4 \mathrm{U}>9 \mathrm{U}-10 \mathrm{~A}>8 \mathrm{U}-9 \mathrm{U} \geq 15 \mathrm{U}-16 \mathrm{~A}$. It should be mentioned, that all SPCs hydrolyze Flu-r(pC) ${ }_{23}$ less efficiently than Flu-r $(\mathrm{pU})_{23}$ and Flu-r(pA) ${ }_{23}$ (Figure 5B), while the major cleavage sites of Flu-miR-137 correspond only after A or U nucleotides. One cannot exclude, that hydrolysis of RONs before and after C-base is thermodynamically less favorable. The relative activities of the SPC preparations in the hydrolysis of RONs are summarized in Table 2.

SPCs efficiently hydrolyze ATP (Figure 6A) and p-nitrophenylphosphate (Figure 6B). Figure 6C shows kinetic curves of optical density changes in the reaction of proteolytic hydrolysis of azocasein by three SPCs. All three SPCs possess amylase activity (Figure 6D). The RAs of the SPCs in the hydrolysis of ATP, p-nitrophenylphosphate, azocasein, and maltoheptaose are summarized in Table 2 .

\begin{tabular}{|c|c|c|c|c|}
\hline & Type of reaction & SPC-1 & SPC-2 & SPC-3 \\
\hline \multirow{2}{*}{1} & DNase (pmole DNA/h/mg & $88.0 \pm 7.0$ & $62.0 \pm 3.0$ & $71.0 \pm 5.0$ \\
\cline { 2 - 5 } & Flu-r(pU)23 (mM ORN/h/mg) & $93.3 \pm 9.0$ & $98.3 \pm 9.2$ & $121 \pm 11.4$ \\
\hline \multirow{2}{*}{2} & $\begin{array}{c}\text { RNase Flu-r(pA)23 (mM ORN/h/ } \\
\mathrm{mg})\end{array}$ & $58.2 \pm 5.0$ & $25.3 \pm 2.1$ & $88.5 \pm 8.0$ \\
\cline { 2 - 5 } & Flu-r(pC)23 (mM ORN/h/mg) & $37.3 \pm 3.1$ & $39.7 \pm 3.6$ & $79.3 \pm 6.9$ \\
\hline \multirow{2}{*}{3} & Flu-miR-137 (mM ORN/h/mg) & $193.8 \pm 18.1$ & $201 \pm 17.0$ & $201 \pm 17.2$ \\
\cline { 2 - 5 } & ATPase activity (M ATP/h/mg) & $0.12 \pm 0.01$ & $0.33 \pm 0.01$ & $0.09 \pm 0.01$ \\
\hline 4 & $\begin{array}{c}\text { Phosphatase activity (M } \\
\text { pNPP/h/mg) }\end{array}$ & $0.16 \pm 0.01$ & $0.14 \pm 0.01$ & $0.1 \pm 0.01$ \\
\hline 5 & $\begin{array}{c}\text { Protease activity (A436 } \\
\text { azocasein /h/mg) }\end{array}$ & $2.8 \pm 0.2$ & $4.9 \pm 0.2$ & $2.2 \pm 0.17$ \\
\hline 6 & Amylase (mM MHS/h/mg) & $16.7 \pm 1.3$ & $38.9 \pm 2.1$ & $30.6 \pm 2.5$ \\
\hline 7 & $\begin{array}{c}\text { Catalase activity (mM H} \mathrm{O}_{2} / \\
\mathrm{min} / \mathrm{mg})\end{array}$ & $1.2 \pm 0.10$ & $6.5 \pm 0.5$ & $16.0 \pm 1.4$ \\
\hline 8 & $\begin{array}{c}\text { Peroxidase activity (mM DAB/ } \\
\mathrm{min} / \mathrm{mg})\end{array}$ & $11.2 \pm 1.0$ & $11.1 \pm 0.7$ & $11.5 \pm 0.8$ \\
\hline 9 & $\begin{array}{c}\text { Oxidoreductase activity(mM } \\
\text { DAB/min/mg) }\end{array}$ & $22.8 \pm 1.6$ & $2.9 \pm 0.17$ & $9.2 \pm 0.7$ \\
\hline
\end{tabular}

${ }^{a}$ For all specific activities of three SPCs a mean value and deviation of three independent measurements is reported.

Table 2: Specific activities of three SPCs in the catalysis of nine different reactions ${ }^{\text {a }}$.
A
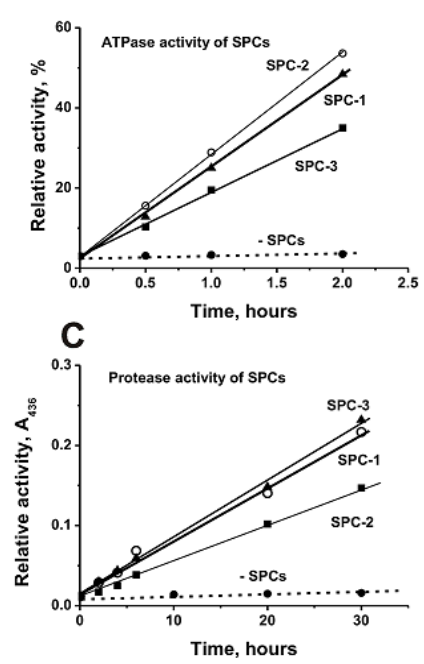

B

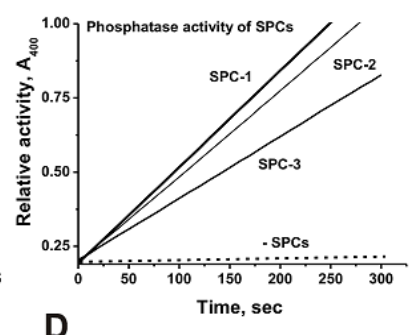

Amylase activity

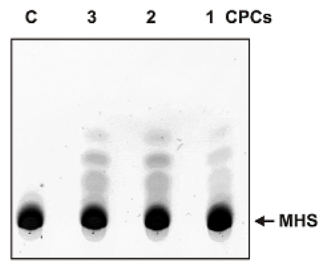

Figure 6: Typical kinetic curves characterizing ATPase (A), phosphatase (B), protease (C) and amylase (D) activities of three SPCs. SPCs $(0.05 \mathrm{mg} / \mathrm{ml}$ (A and B), $0.017 \mathrm{mg} / \mathrm{ml} \mathrm{SPC} \mathrm{(C)} \mathrm{and} \mathrm{(D)} \mathrm{and} \mathrm{substrates} \mathrm{(1.0} \mathrm{mM} \mathrm{ATP} \mathrm{and} \mathrm{para-}$ nitrophenylphosphate; $3.3 \mathrm{mg} / \mathrm{ml}$ azocasein, and $5 \mathrm{mM}$ maltoheptaose) were used in different concentrations.
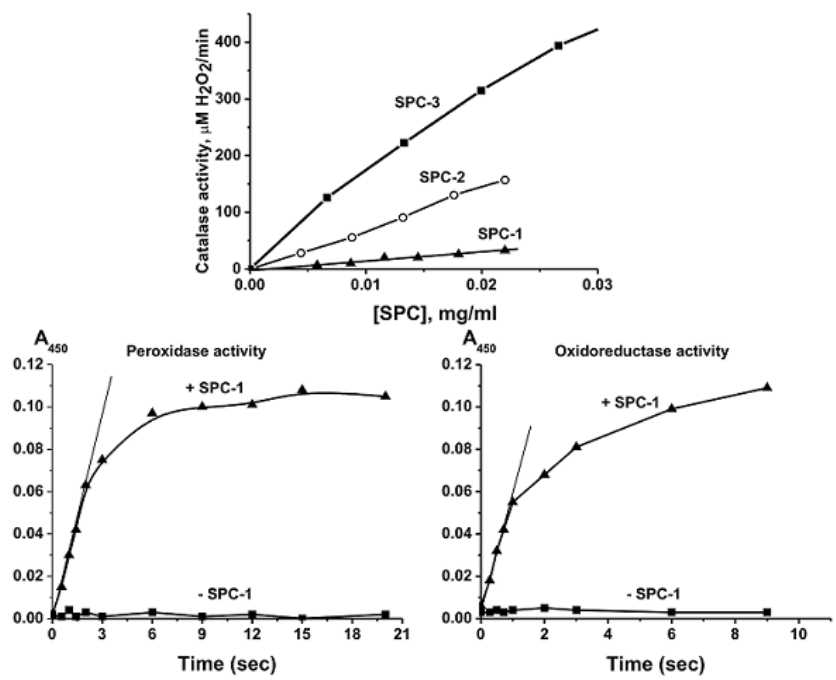

Figure 7: Dependence of the relative catalase activity on the concentration of three SPCs at fixed $30 \mathrm{mM}$ concentration of $\mathrm{H}_{2} \mathrm{O}_{2}$ (A). Typical time-dependent changes in the formation of the product of $D A B(0.55 \mathrm{mM})$ oxidation by SPC1 in the presence (peroxidase activity) (B) and in the absence (C) of $\mathrm{H}_{2} \mathrm{O}_{2}$ (peroxidase activity). The $A_{450}$ changes in the presence and the absence of SPC-1 are shown.

All three SPCs possess catalase (Figure 7A), peroxidase $\left(\mathrm{H}_{2} \mathrm{O}_{2}-\right.$ dependent oxidation of 3,3'-diaminobenzidine) (Figure 7B), and oxidoreductase $\left(\mathrm{H}_{2} \mathrm{O}_{2}\right.$-independent oxidation of the substrate) activities (Figure 7C), the RAs of which are given in Table 2.

\section{Discussion}

Recently we have shown, that human placentas contain a very stable complex of proteins $(\sim 1000 \mathrm{kDa})$, which can be destroyed only using very drastic conditions. In this article using 2-D electrophoresis, MS and MS/MS MALDI mass spectrometry data we have established for the first time that this complex consists of twelve proteins: hemoglobin subunits, alkaline phosphatase, cytoplasmic actin, human 
serum albumin, chorionic somatomammotropin hormone, heat shock protein beta-1, peroxiredoxin-1, $78 \mathrm{kDa}$ glucose-regulated protein, protein disulfide isomerase $\mathrm{A} 3$, serotransferrin, annexin $\mathrm{A} 5$, and IgGs (Table 1). Each of these proteins in themselves possesses multiple very different biological functions (see below).

In this article, it was shown, that the stable complex possesses nine different enzymatic activities: DNase, RNase, ATPase, phosphatase, protease, amylase, catalase, peroxidase $\left(\mathrm{H}_{2} \mathrm{O}_{2}\right.$-dependent oxidation of substrate) and oxidoreductase $\left(\mathrm{H}_{2} \mathrm{O}_{2}\right.$-independent oxidation of substrate) activities (Table 2).

It is known that some proteins of biological fluids and cells in themselves do not possess any enzymatic activities. At the same time, they can exhibit certain properties of enzymes or acquire other new biological functions after the formation of oligomeric complexes with other proteins and/or enzymes [4]. In addition, new active centers of enzymes may often be formed at the interface of different protein globules having in the individual state only partial fragments of final active centers of oligomers. Sometimes some proteins after the formation of specific complexes with others ones can acquire a function of effectors that enhance the efficiency of the catalysis or binding with specific ligands [4]. Some of the revealed nine enzymatic activities of the SPC can be provided by proteins located directly on the surface of the complex or in its deeper layers, which are accessible for enzyme substrates.

What possible biological function of detected enzymes and proteins of SPCs is not yet clear. However, the inclusion in a stable complex of twelve different proteins powerfully expands its possible polyfunctional biological functions including specific functions of individual proteins and their possible associates. Considering this, it is reasonable to note potentially presumable biological functions of the SPC in accordance with the functions of its individual proteins.

Thus, the stable complexes contain alkaline phosphatase, which very effectively catalyzes the hydrolysis of p-nitrophenylphosphate (Figure 6B). Phosphatase plays an integral role in metabolism within the liver and development within the skeleton [22].

The complex contains several proteins that are themselves active in the hydrolysis of DNA and RNA. It was shown, that, human serum albumin has RNase activity [23-25], while IgGs possess relatively low DNase and RNase activities [26-29]. However, it is yet not clear which of these proteins or any combination of the complex proteins can hydrolyze specifically Flu-miR-137 only on four sites (Figure 5C). It cannot be ruled out, that some associates of these two proteins or some of their associates with other ones entering the complex can form active sites for specific hydrolysis of Flu- miR-137. HSA is an important major protein of human blood having very important physiological and biochemical functions [30]. It is responsible for maintaining osmotic pressure, and it may influence on microvascular integrity as well as aspects of the inflammatory pathway, including neutrophil adhesion and the activity of cell signaling moieties; it possesses general antioxidant functions and protection from lipid peroxidation. IgGs have four major effector functions: 1) neutralization of antigens, 2) antibody opsonization, 3) complement fixation, and 4) antibody dependent cell-mediated cytotoxicity [30].

In addition to DNase and RNase activities, human IgGs with catalytic activities (abzymes) are also possess very well detectable ATPase, amylase, and protease activities [26-29]. Thus, these proteins of the SPCs can catalyze the hydrolysis of ATP, oligosaccharides, and azocasein. However, one cannot exclude, that any associates of these proteins or their complexes with other enzymes or proteins can also catalyze these reactions.

The specific ATPase and phosphatase activities of three SPCs are given in Table 2. Classical ATPases are enzymes of the plasma membrane of all animal cells, which specifically accumulates potassium ions in the cell and pumps sodium ions outward using ATP energy for this work $[31,32]$. In known specific protein complex containing ATPase, this enzyme powers lipopolysaccharide transport from the cytoplasmic membrane across the cell envelope [33]. Classical amylases have at least three distinct biological functions including digestion of carbohydrates, may contribute to bacterial clearance and nutrition and an important role in the adhesion of alpha-amylase-binding bacteria [34]. Typical proteases mediate different processes including blood coagulation, an effect on immune function, bone formation, maturation of prohormones, apoptosis, antigen presentation and leukocyte migration, and the recycling of cellular proteins that are no longer needed [35].

Like horseradish peroxidase, some other proteins can also efficiently decompose hydrogen peroxide demonstrating not only peroxidase but also catalase activity [36-38]. It can be assumed that in the catalysis of degradation of hydrogen peroxide, as well as the oxidation of $3,3^{\prime}$-diaminobenzidine (DAB) in the presence and absence of $\mathrm{H}_{2} \mathrm{O}_{2}$ can participate several proteins that enter the stable complex: hemoglobin, peroxiredoxin-1, HSA, and IgGs. It was shown, that hemoglobin possesses peroxidase activity [39-41]. Peroxiredoxins have catalase and peroxidase activities [42-44]. In the presence of $\mathrm{H}_{2} \mathrm{O}_{2}$ human serum albumin is capable with low efficiency to oxidize DAB [45,46]. It was revealed, that IgGs (abzymes) from healthy humans possess catalase, peroxidase, and oxidoreductase activities [26-29].

Hemoglobin releases the oxygen to permit an aerobic providing energy to power the functions of the organism metabolism [39]. Perodixins are antioxidant enzymes, which reduce $\mathrm{H}_{2} \mathrm{O}_{2}$ and alkyl hydroperoxides and may play an antioxidant protective function in cells, and may contribute to the antiviral activity of CD8 (+) T-cells [47]. 78 $\mathrm{kDa}$ glucose regulating protein is a heat shock protein of endoplasmic reticulum of cells involved in protein folding; it plays a role in cancer cell proliferation [48]. Cytoplasmic actin participates in several important cellular processes, including cell signaling, cell motility, cell division and cytokinesismuscle contraction, organelle and vesicle movement, and the establishment and maintenance of cell shape and cell junctions [49]. Chorionic somatomammotropin hormone (or human placental lactogen or chorionic growth hormone prolactin) affects metabolic homeostasis by regulating key enzymes and transporters associated with glucose and lipid metabolism in several target organs [50]. In the lactating mammary gland, it increases the production of milk proteins, lactose, and lipids. High-mobility group box 1 is a nuclear nonhistone DNA binding protein with key roles in maintaining nuclear homeostasis [51]. Heat shock protein beta 1 is a member of the small heat shock protein family, and it is involved in a wide variety of cellular processes. It was originally described as an intracellular chaperone able to stabilize the actin cytoskeleton in response to various stresses. Annexin A5 is commonly used for detection of apoptotic cells by its ability to interact with phosphatidylserine, a known marker of cell apoptosis when it is on the outer leaflet of the plasma membrane. All functions of the protein are unknown exactly, but, annexin A5 has been proposed to play a role in the inhibition of blood coagulation due to competing for phosphotidylserine binding sites with as well as to inhibit the activity of phospholipase A1 [52]. Protein disulfide isomerase catalyzes the formation and breakage of disulfide within proteins as they fold [53]. Serotransferrin is iron binding transport protein also having a role in stimulating cell proliferation [54]. 
Citation: Burkova EE, Dmitrenok PS, Bulgakov DV, Ermakov EA, Buneva VN, et al. (2018) Identification of Major Proteins of a Very Stable High Molecular Mass Multi-Protein Complex of Human Placental Tissue Possessing Nine Different Catalytic Activities. Biochem Anal Biochem 7: 351. doi: 10.4172/2161-1009.1000351

One cannot exclude that all or at least part of these plenty different functions including enzymatic ones of the twelve complex proteins can be important for providing a set of SPC multifunctional properties in the female placenta. In addition, these different functions of SPC and its proteins may be important for the development of protective functions of the mother's organisms, as well as well for protecting the embrio from any harmful factors.

In overall, we have here shown for the first time that soluble fraction of placental proteins contained an extremely stable complex containing twelve proteins and analyzed the SPC catalytic functions.

\section{Acknowledgments}

This research was supported by grants from Russian Foundation for Basic Research (16-04-00609), the Presidium of the Russian Academy of Sciences (Molecular and Cellular Biology Program, 6.2), and funds from the Siberian Division of the Russian Academy of Sciences (1.7.15)

\section{References}

1. Dischof $P$, Klopper AA (1984) Proteins of the placenta. Biochemistry, Biology, and Clinical application. Basel Munchen, Karger, NY, pp: 1-205.

2. Garnica AD, Chan WY (1996) The role of the placenta in fetal nutrition and growth. J Am Coll Nutr 15: 206-222.

3. Alberts B (1998) The cell as a collection of protein machines: preparing the next generation of molecular biologists. Cell 92: 291-294.

4. Eubel H, Braun HP, Millar AH (2005) Blue-native PAGE in plants: a tool in analysis of protein-protein interactions. Plant Methods 1: 11

5. Bohn H, Winckler W, Grundmann U (1991) Immunochemically detected placental proteins and their biological functions. Arch Gynecol Obstet 249: 107-118.

6. Than NG, Sumegi B, Than GN, Berente Z, Bohn H (1999) Isolation and sequence analysis of a cDNA encoding human placental tissue protein 13 (PP-13), a new lysophospholipase, homologue of human eosinophil CharcotLeyden crystal protein. Placenta 20: 703-710.

7. Burger O, Pick E, Zwickel J, Klayman M, Meiri H, et al. (2004) Placental protein 13 (PP-13): effects on cultured trophoblasts, and its detection in human body fluids in normal and pathological pregnancies. Placenta 25: 608-622.

8. Robinson JM, Ackerman WE, Kniss DA, Takizawa T, Vandre DD (2008) Proteomics of the human placenta: promises and realities. Placenta 29: 135-143.

9. Zhang Y, Zhang YL, Feng C, Wu YT, Liu AX, et al. (2008) Comparative proteomic analysis of human placenta derived from assisted reproductive technology. Proteomics 8: 4344-4356.

10. Zhang Q, Schulenborg T, Tan T, Lang B, Friauf E, et al. (2010) Proteome analysis of a plasma membrane-enriched fraction at the placental feto-maternal barrier. Proteom Clin Appl 4: 538-549.

11. Johnstone ED, Sawicki G, Guilbert L, Winkler-Lowen B, Cadete VJ, et al (2011) Differential proteomic analysis of highly purified placental cytotrophoblasts in pre-eclampsia demonstrates a state of increased oxidative stress and reduced cytotrophoblast antioxidant defense. Proteomics 11:4077-4084.

12. Wang F, Wang L, Liang G (2013) Identification and analysis of multi-protein complexes in placenta. PLoS One 138: e62988.

13. Burkova EE, Dmitrenok PS, Sedykh SE, Buneva VN, Soboleva SE, et al. (2014) Extremely stable soluble high molecular mass multi-protein complex with DNase activity in human placental tissue. PLoS One 9: e111234.

14. Kanyshkova TG, Babina SE, Semenov DV, Isaeva N, Vlassov AV, et al. (2003) Multiple enzymic activities of human milk lactoferrin. Eur J Biochem 270: 33533361.

15. Vlassov A, Florentz C, Helm M, Naumov V, Buneva V, et al. (1998) Characterization and selectivity of catalytic antibodies from human serum with RNAse Activity. Nucleic Acids Res 26: 5243-5250.

16. Mertz P, Yu L, Sikkink R, Rusnak F (1997) Kinetic and spectroscopic analyses of mutants of a conserved histidine in the metallophosphatases calcineurin and lambda protein phosphatase. J Biol Chem 272: 21296-21302.

17. Charney J, Tomarelli RM (1947) A colorimetric method for the determination of the proteolytic activity of duodenal juice. J Biol Chem 171: 501-505.
18. Andryushkova A., Kuznetsova IA, Orlovskaya IA, Buneva VN, Nevinsky GA (2006) Antibodies with amylase activity from the sera of autoimmune-prone MRL/MpJ-Ipr mice. FEBS Lett 580: 5089-5095.

19. Aebi H (1984) Catalase in vitro. Methods Enzymol 105: 121-130.

20. Harris DC (2002) Quantitative Chemical Analysis, 6th ed. WH Freeman and Company. New York.

21. Tolmacheva AS, Zaksas NP, Buneva VN, Vasilenko NL, Nevinsky GA (2009) Oxidoreductase activities of polyclonal lgGs from the sera of Wistar rats are better activated by combinations of different metal ions. J Mol Recognit 22: 26-37.

22. Millan JL (2006) Alkaline Phosphatases: structure, substrate specificity and functional relatedness to other members of a large superfamily of enzymes. Purinergic Signal 2: 335-341.

23. Gerasimova YV, Knorre D., Shakirov MM, Godovikova TS (2008) Human serum albumin as a catalyst of RNA cleavage: N-homocysteinylation and $\mathrm{N}$-phosphorylation by oligonucleotide affinity reagent alter the reactivity of the protein. Bioorg Med Chem Lett 18: 5396-5398.

24. Gerasimova YV, Erchenko IA, Shakirov MM, Godovikova TS (2008) Interaction of human serum albumin and its clinically relevant modification with oligoribonucleotides. Bioorg Med Chem Lett 18: 4511-4514.

25. Tomar HH, Chaudhary NS, Priyadarshi O, Gahloth D, Patel GK, et al. (2014) Purification, characterisation and cloning of a $2 \mathrm{~S}$ albumin with DNase, RNase and antifungal activities from Putranjiva roxburghii. Appl Biochem Biotechnol 174: $471-482$.

26. Nevinsky GA, Buneva VN (2005) Natural catalytic antibodies - abzymes. In Keinan E (ed.) Catalytic antibodies. Weinheim, VCH-Wiley Press: Germany, pp: 503-569.

27. Nevinsky GA (2010) Natural catalytic antibodies in norm and in autoimmun diseases. In: Brenner KJ (ed.) Autoimmune Diseases: Symptoms, Diagnosis and Treatment. USA: Nova Science Publishers Inc, pp: 1-107.

28. Nevinsky GA (2011) Natural catalytic antibodies in norm and in HIV-infected patients, In: Kasenga FH (ed.) Understanding HIVIAIDS Management and Care - Pandemic Approaches the 21st Century. Rijeka, Croatia: InTech, pp: 151-192.

29. Nevinsky GA (2016) Autoimmune processes in multiple sclerosis: production of harmful catalytic antibodies associated with significant changes in the hematopoietic stem cell differentiation and proliferation. In: Conzalez-Quevedo A (ed.) Multiple sclerosis. Rijeka, Croatia: InTech, pp: 100-147.

30. Quinlan GJ, Martin GS, Evans TW (2005) Albumin: biochemical properties and therapeutic potential. Hematology 41: 1211-1219.

31. Shin JM, Munson K, Vagin O, Sachs G (2009) The gastric HK-ATPase: structure, function and inhibition. Pflugers Arch 457: 609-622.

32. Berg JM, Tymoczko JL, Stryer L (2012) Biochemistry (7thedn), W.H. New York Freeman and Company.

33. Sherman DJ, Lazarus MB, Murphy L, Liu C, Walker S, et al. (2014) Decoupling catalytic activity from biological function of the ATPase that powers lipopolysaccharide transport. Proc Natl Acad Sci. USA 111: 4982-4987.

34. Scannapieco FA, Torres G, Levine MJ (1993) Salivary alpha-amylase: role in dental plaque and caries formation. Crit Rev Oral Biol Med 4: 301-307.

35. Ivanov D, Emonet C, Foata F, Affolter M, Delly M, et al. (2006) A serpin from the gut bacterium Bifidobacterium longum inhibits eukaryotic elastase like serine proteases. J Biol Chem 281: 17246-17252.

36. Allen RG (1998) Free radicals in aging. Boca Raton: FL CPC Press

37. Ceballos-Picot I, Nicole A, Clement M, Bourre JM, Sinet PM (1992) Age-related changes in antioxidant enzymes and lipid peroxidation in brains of control and transgenic mice overexpressing copper-zinc superoxide dismutase. Mutat Res 275: 281-293.

38. Zenkov NK, Lankin VZ, Men'shikova EB (2001) Oxidative stress. Biochemical and pathophysiological aspects. MAIK, Nauka/Interperiodica. Germany, pp: 3-343.

39. Wang Y, Barbeau X, Bilimoria A, Lagüe P, Couture M, et al. (2015) Peroxidase activity and involvement in the oxidative stress response of roseobacter denitrificans truncated hemoglobin. PLoS One 10: e0117768.

40. Zhao J, Zhao J, Franzen S (2013) The regulatory implications of hydroquinone for the multifunctional enzyme dehaloperoxidase-hemoglobin from Amphitrite ornata. J Phys Chem B 117: 14615-14624. 
Citation: Burkova EE, Dmitrenok PS, Bulgakov DV, Ermakov EA, Buneva VN, et al. (2018) Identification of Major Proteins of a Very Stable High Molecular Mass Multi-Protein Complex of Human Placental Tissue Possessing Nine Different Catalytic Activities. Biochem Anal Biochem 7: 351. doi: 10.4172/2161-1009.1000351

Page 9 of 9

41. Kvist M, Ryabova ES, Nordlander E, Bülow L (2007) An investigation of the peroxidase activity of Vitreoscilla hemoglobin. J Biol Inorg Chem 12: 324-334.

42. Sun CC, Dong WR, Shao T, Li JY, Zhao J, et al. (2017) Peroxiredoxin 1 (Prx1) is a dual-function enzyme by possessing Cys-independent catalase-like activity. Biochem J 474: 1373-1394.

43. Rhee SG, Yang KS, Kang SW, Woo HA, Chang TS (2005) Controlled elimination of intracellular $\mathrm{H} 2 \mathrm{O} 2$ : regulation of peroxiredoxin, catalase, and glutathione peroxidase via post-translational modification. Antioxid Redox Signal 7: 619-626

44. Nevalainen TJ (2010) 1-Cysteine peroxiredoxin: A dual-function enzyme with peroxidase and acidic Ca2+-independent phospholipase A2 activities. Biochimie 92: 638-644.

45. Tolmacheva AS, Blinova EA, Ermakov EA, Buneva VN, Vasilenko NL, et al (2015) IgG abzymes with peroxidase and oxidoreductase activities from the sera of healthy humans. J Mol Recognit 28: 565-580.

46. Anthea M, Hopkins J, McLaughlin CW, Johnson S, Warner MQ, et al. (1993) Human Biology and Health. Prentice Hal: Englewood Cliffs. New Jersey. USA.

47. Knoops B, Argyropoulou V, Becker S, Ferté L, Kuznetsova O (2016) Multiple roles of peroxiredoxins in inflammation. Mol Cells 39: 60-64.
48. Macias AT, Williamson DS, Allen N, Borgognoni J, Clay A, et al. (2011) Adenosine-derived inhibitors of $78 \mathrm{kDa}$ glucose regulated protein (Grp78) ATPase: insights into isoform selectivity. J Med Chem 54: 4034-4041.

49. Henney CS (1979) The "triggering" of cytotoxic cell differentiation in secondary cultures by subcellular antigens. J Immunol 122: 2134.

50. Ben-Jonathan N, Hugo E (2015) Human chorionic somato-mammotropin (HCS), proposed terminology for designation of a placental hormone. Adv Exp Med Biol 846: 1-35.

51. Narumi T, Shishido T, Otaki Y, Kadowaki S, Honda Y, et al. (2015) Highmobility group box 1 -mediated heat shock protein beta 1 expression attenuates mitochondrial dysfunction and apoptosis. J Mol Cell Cardiol 82: 1-12.

52. Belhocine TZ, Blankenberg FG, Kartachova MS, Stitt LW, Vanderheyden JL et al. (2015) 99mTc-Annexin A5 quantification of apoptotic tumor response: systematic review and meta-analysis of clinical imaging trials. Eur J Nucl Med Mol Imaging 42: 2083-2097.

53. Gruber CW, Cemazar M, Heras B, Martin JL, Craik DJ (2006) Protein disulfide isomerase: the structure of oxidative folding. Trends in Biochem Sci 31: 455-464.

54. Luck AN, Mason AB (2012) Transferrin-mediated cellular iron delivery. Curr Top Membr 69: 3-35. 